\title{
二次元超音速インテークの流れ特性と制御に関する研究
}

\section{A Study on the Characteristics and Control of a Two-Dimensional Supersonic Intake Flow}

\author{
O 学 東田 憲幸（室蘭エ大·院） 正 杉山 弘（室蘭工大） \\ 正 溝端一秀（室蘭工大） 正 湊 亮二郎（室蘭工大） \\ 学 浅利 元紀（室蘭工大·院）
}

\begin{abstract}
Noriyuki HIGASHIDA, Muroran Institute of Technology, 27-1, Mizumoto, Muroran, 050-8585
Hiromu SUGIYAMA, Muroran Institute of Technology

Kazuhide MIZOBATA, Muroran Institute of Technology

Ryojiro MINATO, Muroran Institute of Technology

Motoki ASARI, Muroran Institute of Technology
\end{abstract}

Key Words : Supersonic Intake, Intake Aerodynamics, Shock Wave, Boundary Layer, Cavity Bleed, Flow Visualization, Total Pressure Distribution

1. はじめに

次世代の完全再使用型宇宙往還機の推進システムとして, 大気中の酸素を酸化剂として利用する空気吸込み式エンジ ン(Air-Breathing Engine)が有望視されている.このエンジン において重要な構成要素の一つは, 超音速インテークであ る，超音速インテークは，超音速で流れる空気を内部に取 り込み，衝撃波を利用し亜音速まで，取り込んだ空気を減 速圧縮させるものである ${ }^{(1)}$ ，ところで，インテーク内部の 流れは，インテーク内部壁面に沿って発達する境界層の影 響を大きく受け，流れが超音速の場合には境界層と衝撃波 が複雑に干渉し, 全圧回復率を低下させる原因となるため, その構造や特性を解明することが工学上重要である。

本研究では, 超音速インテークの流れ特性に及ぼすキャ ビティ抽気の影響を，カラーシュリーレン法と油膜法によ る可視化および全圧分布測定を行い，調べた。

\section{2. 実験概要}

使用した風洞は，マッハ数 1.8 の間欠吸い込み式風洞で ある. 流れの可視化のほか, 全圧測定装置によって Fig.1 に示す $X=75 \mathrm{~mm}$ の位置における流路横断面内で時間平均全 圧分布測定を行った。

\section{3.まとめ}

Fig.1 にインテーク内部でキャビティ抽気(キャビティあ り，抽気あり)を行った場合の流れのカラーシュリーレン写 真を示す. Fig.1 より，キャビティ後方で，下壁上の境界層 の厚さの増加が抑えられていることがわかる。これは抽気 によって，第一ランプから発達した境界層を吸い出すこと で，境界層の発達を抑制できたためである.

キャビティあり，抽気なしの場合において，垂直衝撃波 は観察されなかったが, キャビティあり，抽気ありの場合 においては，垂直衝撃波が観察された。このことから，抽 気を行うことで, 衝撃波の発生位置を制御できる可能性が

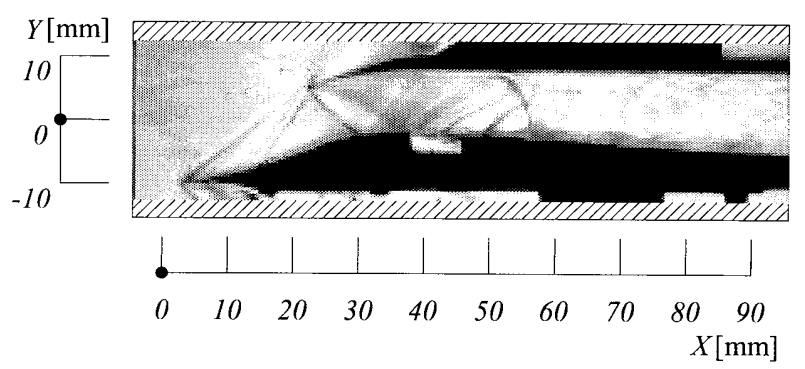

Fig.1 Visualization of the intake internal flow with cavity bleed

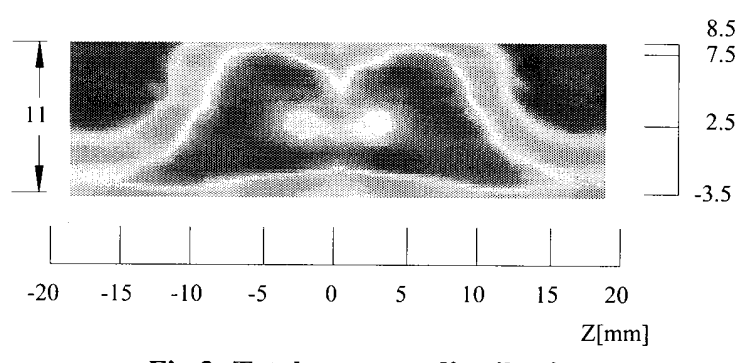

Fig.2 Total pressure distribution

示唆される. $X=75 \mathrm{~mm}$ の位置における流路横断面内で測定 した時間平均全圧分布を Fig.2 に示す. Fig.2 より，ランプ 中央断面付近での全圧は抽気を行わない場合と比較すると, 全圧は増加しているのがわかった．また，ランプと側壁の な寸コーナーにおいて抽気を行わない場合と比較して，全 压が増加している領域が拡大していることがわかった。

参考文献

(1) Seddon, J. and Goldsmith, E.L., Intake Aerodynamics, Second Edition, AIAA Educaiton Series, (1999), pp.5-15. 